\title{
DIGITAL TRANSFORMATION IN TOURISM EDUCATION
}

\author{
Ana Balula \\ Gillian Moreira \\ António Moreira \\ Elisabeth Kastenholz \\ Celeste Eusébio \\ Zélia Breda
}

https://doi.org/10.20867/tosee.05.45

\begin{abstract}
Purpose - Digital technology is an undeniable prime mover of society, and the ongoing digital transformation seems to be increasing the challenges within Tourism Education. Thus, this study aims at identifying, in the literature, advantages and constraints it poses to the area.

Methodology - This work follows a literature review methodology, focusing on peer-reviewed, open source, recently published research, and the selected papers were analysed though a content analysis.

Findings - The results yielded that teachers and students agree that some of the clear advantages of using digital technology in Tourism Education are: i) time and space flexibility, ii) the development of technical/systemic competencies, and iii) the possibilities it opens for authentic/situated teaching and learning. Furthermore, even though the use of digital technology appears to have a positive effect on students' engagement, there is still some way to go to fully address the development of the students' and teachers' digital competence.

Contributions - This study makes a valuable contribution to the current discussion around the need to reshape Tourism Education by addressing not only students' but also faculty members' needs. It has a dual focus, i.e. on the use of digital technology in teaching and learning; and on the development of digital competence. Even though it concerns Tourism in specific, the results of this paper can be seen as a contribution to the state of the art of upcoming and ongoing projects in the Educational area - e.g. "Future Proof Your Classroom - Teaching Skills 2030" (ref. 2017-1AT01-KA203-034984).
\end{abstract}

Keywords digital transformation; Tourism Education; research; best practices

\section{INTRODUCTION}

Tourism Education has evolved from a strong vocational origin and is, therefore, highly industry-driven (Xiao, Qiu and Cheng, 2018). Thus, Tourism courses focus on responding to practical challenges within this specific, however complex and highly dynamic, economic sector. Prominent examples of such experiential learning are work placements, teaching restaurants/kitchens, and fieldtrips. Likewise, case study and problem-based learning approaches help students get a better understanding of 'real life' situations and challenges (Dart 2009).

In fact, the impact of digital technology, particularly in the field of Tourism, is unquestionable and frequently considered a driver of innovation in the sector (Dexeus 2019; Law, Buhalis and Cobanoglu 2014). Not only does digital technology allow for 
ToSEE - Tourism in Southern and Eastern Europe, Vol. 5, pp. 61-72, 2019

A. Balula, G. Moreira, A. Moreira, E. Kastenholz, C. Eusébio, Z. Breda: DIGITAL TRANSFORMATION ...

improved customer adaptation and added-value for the traveller, particularly in terms of travel planning, informed decision-making, orientation on-site, but also for experience enhancement within certain service and destination settings, and last but not least, for experience sharing with others. This increasing role of technology within the travel experience, before, during and after travel, has 'revolutionized' Tourism (Dexeus 2019). Additionally, digital technology contributes to a more efficient and competitive organization of tourism products that should be understood as complex, integrated experience opportunities, involving a variety of economic, social and cultural actors and resources (Framke 2002).

At the European level, the Joint Research Centre of the European Commission on Learning and Skills for the Digital Era highlights the importance of "harnessing the potential of digital technologies to innovate education and training practices, improve access to lifelong learning and to deal with the rise of new (digital) skills and competencies needed for employment, personal development and social inclusion" (Carretero, Vuorikari and Punie 2017, 6). This effort has been translated into detailed guidelines, such as the DigComp 2.1: The Digital Competence Framework for Citizens (DigComp) and the Digital Competence Framework for Educators (DigCompEdu). At the same time, according to the World Economic Forum's $(2017,5)$ latest report: "The greatest societal impact may be the effect of digital transformation on the travel workforce, which could represent as many as one in every 11 jobs worldwide by 2025 . Intelligent automation will change the nature of some travel jobs and eradicate others altogether". In this scenario, it is vital for Higher Education Institutions (HEI), especially in the field of Tourism (and Hospitality) Education, to keep pace with enduring digital transformation.

The Internet information space is easily available and accessible worldwide to travellers, tourism industry agents, but also researchers, teachers and students, and has become increasingly complex and dynamic. Considering this, the use of digital technologies enhancing efficient communication and articulation between the different Tourism actors within destination networks and markets should be recognized as valuable for business success (Dexeus 2019; Law, Buhalis and Cobanoglu 2014). Thus, HEI and, most importantly, teachers, need to be prepared to integrate digital technology successfully into Tourism curricula, since it helps foster situated learning and engagement with authentic cases, agents and contexts. For their part, students need to understand the role and potentialities of digital technologies, but they also need to know how to use them, to be better prepared for their future positions within the tourism system. And finally, it is also important that research addresses this ever-changing framework and provides evidence for finding adequate, efficient and sustainable uses of digital technology in Tourism Education. Taking this into account, this study aims to present the results of a literature review focusing on evidence of digital transformation within Tourism Education, outlining best practices and trends, highlighting key findings, thus paving the way for research and practice in the area. 
ToSEE - Tourism in Southern and Eastern Europe, Vol. 5, pp. 61-72, 2019

A. Balula, G. Moreira, A. Moreira, E. Kastenholz, C. Eusébio, Z. Breda: DIGITAL TRANSFORMATION ...

\section{METHODOLOGY}

This study is of an exploratory nature and focuses on finding evidence of how digital transformation is making its way into Tourism Education. It follows a literature review methodology, focusing on peer-reviewed, open source, recently published research. Data was gathered based on the following criteria: i) the selected databases were to include international, open access, scholarly peer-reviewed journals; accordingly, the databases selected were B-on, Directory of Open Access Journals, Eric, Google Scholar, Semantic Scholar, European Union Digital Library, Scopus, RCAAP (Repositório Científico de Acesso Aberto de Portugal) and Web of Science; ii) the search terms were ESP, Tourism Education, Higher Education, digital technology - combined using the Boolean operators OR and AND; iii) the search was restricted to the timeframe 2017 to 2019; and iv) the documents had to be written in English.

The search was carried out between 27th and 29th December 2018. The results were then reviewed to eliminate duplication. This process yielded 84 documents from a variety of sources: B-on: 24; Directory of Open Access Journals - 0; Eric - 25; European Union Digital Library - 0; Google Scholar - 35; RCAAP - 0; Semantic Scholar - 0; and Web of Science - 0. A thorough content analysis based on relevance as to evidence of digital transformation within Tourism Education resulted in the selection of 14 documents.

The selected sources were subjected to content analysis by systematically interpreting and coding the data collected with the support of qualitative data analysis software, and drawing replicable and valid inferences derived from the emerging categories. The key principles, concepts and best practices identified from the data will be relevant to further research and practice. Although this study is concerned with the specific area of Tourism, the results of this paper, both qualitative and quantitative - where relevant - , are a useful contribution to the state of the art of upcoming and on-going projects in the educational field, e.g.: "Future Proof Your Classroom - Teaching Skills 2030" (ref. 2017-1-AT01KA203-034984).

The various categories that emerged from our reading of the literature were reduced to four core categories that were deployed against indicators recorded as evidence from the respective documental sources: (i) Delivery mode of delivery - online modes of course delivery, regardless of type (e.g. m-b-e-Learning, MOOCs, etc.; (ii) Web paradigm (from Web 0.5 to Web 5.0), subsuming various digital technologies used in Tourism Education; (iii) the main advantages, and (iv) constraints identified in this context. Blind triangulation of coding and recoding processes was employed to fine-tune the interpretation of results.

\section{FINDINGS}

As pointed out in many of the studies analysed, there is a clear trend towards digitalization in Tourism (and Hospitality) Education (e.g. Enticknap-Seppänen 2017; Lugosi and Jameson 2017; Patiar, Ma, Kensbock and Cox 2017; Tavakoli and Wijesinghe 2019). Chiao, Chen and Huang (2017) state that digital technology acts as an important means of introducing innovation for Tourism organisations, practitioners 
ToSEE - Tourism in Southern and Eastern Europe, Vol. 5, pp. 61-72, 2019

A. Balula, G. Moreira, A. Moreira, E. Kastenholz, C. Eusébio, Z. Breda: DIGITAL TRANSFORMATION ...

and educators. In this scenario, it is important to understand how Tourism Education is keeping pace with the ubiquitous nature of digital technology and its development, as well as the promotion of the teachers' and students' digital proficiency.

A first analysis of the corpus gathered for this study focussed on the identification of the teaching and learning delivery modes reported and the most recurrent web paradigms used in Tourism Education and Research (see Table 1).

Table 1: Delivery modes and web paradigms in Tourism Education and Research

\begin{tabular}{l|l|l} 
Categories & Indicators \\
\multirow{2}{*}{$\begin{array}{l}\text { Delivery } \\
\text { mode }\end{array}$} & $\begin{array}{l}\text { Online learning does not replace face- } \\
\text { to-face learning }\end{array}$ & Lugosi and Jameson (2017) \\
\cline { 2 - 3 } & $\begin{array}{l}\text { Online learning offers tend to be } \\
\text { defined at the organisational level } \\
\text { (top-down) }\end{array}$ & Lin and Cantoni (2018) \\
\cline { 2 - 3 } & $\begin{array}{l}\text { Online learning offers (e.g. MOOCs) } \\
\text { pose as cost-effective solutions but } \\
\text { imply an increase of workload for } \\
\text { teachers/facilitators/instructors }\end{array}$ & $\begin{array}{l}\text { Xiao, Qiu and Cheng (2018); Lin and } \\
\text { Cantoni (2018); Padron, Fortune, } \\
\text { Spielman and Tjoei (2017); Patiar, } \\
\text { Ma, Kensbock and Cox (2017) }\end{array}$ \\
\cline { 2 - 3 } & $\begin{array}{l}\text { Blended-learning allows for } \\
\text { integrating higher-order practical } \\
\text { competencies with broader subjects }\end{array}$ & $\begin{array}{l}\text { Patiar, Ma, Kensbock and Cox } \\
\text { (2017); Xiao, Qiu and Cheng (2018); } \\
\text { Padron, Fortune, Spielman and Tjoei } \\
\text { (2017) }\end{array}$ \\
\hline \multirow{2}{*}{ Web } & $\begin{array}{l}\text { Tourism Education studies and } \\
\text { practice tend to be conducted on Web } \\
1.0,1.5 \text { and 2.0 }\end{array}$ & $\begin{array}{l}\text { Tavakoli and Wijesinghe (2018); Lin } \\
\text { and Cantoni (2018) }\end{array}$ \\
\cline { 2 - 3 } & $\begin{array}{l}\text { Virtual reality intelligent solutions } \\
\text { (Web 3.0) are seen as effective and } \\
\text { well-accepted in Tourism Education }\end{array}$ & $\begin{array}{l}\text { Chiao, Chen, Huang (2018); Patiar, } \\
\text { Mansensbock and Cox (2017); } \\
\text { Schott (2017); Schaffer (2017) }\end{array}$ \\
\hline
\end{tabular}

Regarding the delivery modes, Lugosi and Jameson (2017) point out that some teachers still fear that online learning will replace face-to-face teaching, in the sense that it may discourage students from coming to class. This seems to be a red herring, since the literature suggests that online materials are mostly used "for revision and assignment preparation rather than as a substitute for lecture attendance" (Lugosi and Jameson 2017, 166), and that students enrolled in blended-learning seem to receive the best of both worlds (Padron, Fortune, Spielman and Tjoei 2017). According to Xiao, Qiu and Cheng (2018), the first Massive Open Online Course (MOOC) in Tourism and Hospitality dates from 2013. In fact, there has been a continuous increase in the offer of this course format since then, mainly due to spending containment of HEI and the need for Tourism and Hospitality curricula to include a wider set of subjects, e.g.: Geography, Sociology, etc.

The study undertaken by Lin and Cantoni $(2018,286)$ also reveals that the adoption of MOOCs tends to result from institutional interest and/or pressure and "the authoritative decision style resulted in a lower possibility of repeating MOOC practices by the early adopters". In fewer cases, the interest in experimenting with technology-based teaching and learning environments and the willingness to share expertise also seem to be important reasons to opt for this delivery mode. 
ToSEE - Tourism in Southern and Eastern Europe, Vol. 5, pp. 61-72, 2019

A. Balula, G. Moreira, A. Moreira, E. Kastenholz, C. Eusébio, Z. Breda: DIGITAL TRANSFORMATION ...

In educational settings, the effectiveness of teaching and learning processes "is dependent upon the user's perceptions of competency and the quality of the actual learning and teaching material, and its mode of delivery" (Patiar, Ma, Kensbock and Cox 2017, 136). According to Lin and Cantoni (2018, 275), only "half of the instructors intended to repeat the experience of teaching in the MOOCs format in the future", especially because of the overwhelming workload involved in their design and implementation. The conclusions of the study developed by Lugosi and Jameson (2017) reinforce these results, and add that MOOCs do not represent a clear cost saving solution for HEIs. Nonetheless, Xiao, Qiu and Cheng (2018) conclude that MOOCs may be a cost-effective and efficient mode to deliver a richer and more integrated curriculum, if embedded in a blended delivery mode. In fact, the combination of online and face-toface learning seems to allow some of the constraints of the adoption of MOOCs to be minimised, namely: "(1) the insufficient hurdle role of MOOC assessments in qualification verification, (2) their inadequacies in training and assessing higher-order practical competencies, and (3) the unfulfilled role of learners as co-creators and coassessors" (Xiao, Qiu and Cheng 2018, 1).

More generally, and with regard to the digital technology used in research and practice in Tourism Education, Tavakoli and Wijesinghe $(2018,48)$ demonstrate that "The majority of tourism netnography studies have been conducted on Web 1.0, Web 1.5 and Web 2.0 (websites, tourism blogs, and social media). Other platforms, using Web 3.0, Web 4.0 and Web 5.0 technologies, are rarely explored by netnographers". These authors provide examples of digital technology that is being (or is expected to be) used in manifold contexts by practitioners, educators and researchers in the field, as presented in Table 2 .

Table 2: Digital technology used in Tourism Education and Research according to web paradigm

\begin{tabular}{l|l} 
Web paradigm & Digital Technology \\
\hline Web 0.5/1.0 & Unidirectional websites, organisation weblogs or blogs \\
\hline Web 1.5 & Content Management Systems (CMS) \\
\hline \multirow{5}{*}{ Web 2.0 } & Personal or corporate weblogs or blogs \\
\cline { 2 - 2 } & Podcasting (e.g. Lonely Planet) \\
\cline { 2 - 2 } & Social networking (e.g. TravelTogether, TravelGirls) \\
\cline { 2 - 2 } & User-generated content (e.g. TripAdvisor) \\
\cline { 2 - 2 } & Online videos (e.g. YouTube, Travelistic) \\
\cline { 2 - 2 } & Rich Site Summary or RSS (e.g. Expedia) \\
\cline { 2 - 2 } & Tagging tools (e.g. Flickr) \\
\cline { 2 - 2 } & Mash-ups and open application programming interfaces \\
\cline { 2 - 2 } & Wikis (e.g. Wikitravel) \\
\hline \multirow{5}{*}{ Web 2.5 } & Social networks for travel reviews (e.g. TripAdvisor) \\
\cline { 2 - 2 } & Navigation applications for route planning and GPS services (e.g. \\
& Waze, Google Maps) \\
\cline { 2 - 2 } & Picture galleries (e.g. Instagram) \\
\hline \multirow{5}{*}{ Web 3.0 } & Second Life - navigating virtual hotels (e.g. Virtual Aloft) \\
\cline { 2 - 2 } & Second Life - navigating virtual destinations (e.g. Eifel Tower) \\
\hline \multirow{2}{*}{ Web 3.5 } & Natural language processors (e.g. Inbenta) \\
\cline { 2 - 2 } & 3D virtual social networks (e.g. vTime) \\
\hline
\end{tabular}


ToSEE - Tourism in Southern and Eastern Europe, Vol. 5, pp. 61-72, 2019

A. Balula, G. Moreira, A. Moreira, E. Kastenholz, C. Eusébio, Z. Breda: DIGITAL TRANSFORMATION ...

\begin{tabular}{l|l} 
Web paradigm & Digital Technology \\
\hline Web 4.0 & $\begin{array}{l}\text { Smart tourism (e.g. tourism digital friend - e-agent; digital friend of } \\
\text { travel) }\end{array}$ \\
\hline Web 5.0 & $\begin{array}{l}\text { 'Sensory-emotion Web' based on artificial intelligence (e.g. technology } \\
\text { that can recognise facial expressions and react to them or add sensorial } \\
\text { emotions to avatars for virtual interaction) }\end{array}$ \\
\hline
\end{tabular}

Source: based on Tavakoli and Wijesinghe (2018)

Teachers and students regard the use of digital technology in HE settings as inevitable; nevertheless, the former recognize the need for understanding how the latter learn through digital technology in order to bring "richness and complexity to the 'traditional' learning experience" (Lugosi and Jameson 2017, 166) and to overcome the digital divide between teachers and students. Given that the use of digital technology in education (in this case, in the field of Tourism) is neither universal and standardised, nor immutable, the studies we analysed in this research identified shortcomings and potentialities of its use in specific cases. Even though the results of these studies are not intended to be generalisable, the categories and indicators presented in Table 3 and Table 4 reflect key aspects that should be taken into account in future efforts to integrate digital technology in Tourism Education.

\section{Table 3: Advantages of using digital technology in Tourism Education}

\begin{tabular}{|c|c|c|}
\hline Category & Indicators & Studies \\
\hline \multirow[t]{7}{*}{ Advantages } & $\begin{array}{l}\text { Keeping track of students' } \\
\text { performance and providing } \\
\text { feedback }\end{array}$ & $\begin{array}{l}\text { Cheung, Wan and Chan (2018); Xiao, Qiu } \\
\text { and Cheng (2018) }\end{array}$ \\
\hline & $\begin{array}{l}\text { Promoting equity among } \\
\text { students }\end{array}$ & $\begin{array}{l}\text { Chiao, Chen and Huang (2017); Schaffer } \\
\text { (2017) }\end{array}$ \\
\hline & $\begin{array}{l}\text { Prompting more } \\
\text { integrated/multidisciplinary } \\
\text { learning }\end{array}$ & $\begin{array}{l}\text { Chiao, Chen and Huang (2017); Lugosi and } \\
\text { Jameson (2017) }\end{array}$ \\
\hline & $\begin{array}{l}\text { Fostering immersive/authentic } \\
\text { learning }\end{array}$ & $\begin{array}{l}\text { Chiao, Chen and Huang (2017); Patiar, Ma, } \\
\text { Kensbock and Cox (2017); Schaffer (2017) } \\
\text { Schott (2017); Enticknap-Seppänen (2017) }\end{array}$ \\
\hline & $\begin{array}{l}\text { Reinforcing students' } \\
\text { professional identity and } \\
\text { awareness }\end{array}$ & $\begin{array}{l}\text { Enticknap-Seppänen (2017); Padron, } \\
\text { Fortune, Spielman and Tjoei (2017); } \\
\text { Schaffer (2017); Patiar, Ma, Kensbock and } \\
\text { Cox (2017) }\end{array}$ \\
\hline & $\begin{array}{l}\text { Fostering student-centred, } \\
\text { flexible learning }\end{array}$ & Patiar, Ma, Kensbock and Cox (2017) \\
\hline & $\begin{array}{l}\text { Enhancing students' intrinsic } \\
\text { learning motivation and } \\
\text { engagement }\end{array}$ & $\begin{array}{l}\text { Chiao, Chen and Huang (2017); Enticknap- } \\
\text { Seppänen (2017); Lugosi and Jameson } \\
\text { (2017); Patiar, Ma, Kensbock and Cox } \\
\text { (2017); Xiao, Qiu and Cheng (2018); } \\
\text { Schaffer (2017); Schott (2017); } \\
\text { Sharafuddin, Sawad and Wongwai (2017) }\end{array}$ \\
\hline
\end{tabular}


ToSEE - Tourism in Southern and Eastern Europe, Vol. 5, pp. 61-72, 2019

A. Balula, G. Moreira, A. Moreira, E. Kastenholz, C. Eusébio, Z. Breda: DIGITAL TRANSFORMATION ...

\begin{tabular}{|l|l|l|} 
Category & Indicators & Studies \\
\hline Advantages & $\begin{array}{l}\text { Promoting the development of } \\
\text { soft skills (i.e. digital } \\
\text { proficiency, leadership, }\end{array}$ & Barbera, Garcia and Fuertes-Alpista (2017); \\
& Cheung, Wan and Chan (2018); Chiao, \\
& communication, social & Chen and Huang (2017); Enticknap- \\
& interaction, collaboration, team & Seppänen (2017); Lin and Cantoni (2018); \\
& Lork, decision making, & Lugosi and Jameson (2017); Padron, \\
& problem-solving, critical & Fortune, Spielman and Tjoei (2017); Patiar, \\
& thinking, etc.) & Ma, Kensbock and Cox (2017) \\
& & Schaffer (2017); Schott (2017); \\
& Sharafuddin, Sawad and Wongwai (2017); \\
\hline
\end{tabular}

Table 4: Constraints of using digital technology in Tourism Education

\begin{tabular}{|c|c|c|}
\hline Category & Indicators & Studies \\
\hline \multirow[t]{6}{*}{ Constraints } & $\begin{array}{l}\text { Teachers lack digital } \\
\text { competence/proficiency }\end{array}$ & Cheung, Wan and Chan (2018) \\
\hline & $\begin{array}{l}\text { Students lack digital } \\
\text { competence/proficiency }\end{array}$ & Lugosi and Jameson (2017) \\
\hline & $\begin{array}{l}\text { Students are uncritical } \\
\text { consumers of information }\end{array}$ & Lugosi and Jameson (2017) \\
\hline & $\begin{array}{l}\text { Technology can act as a } \\
\text { distractor }\end{array}$ & Lugosi and Jameson (2017) \\
\hline & $\begin{array}{l}\text { Teachers consider that digital } \\
\text { technology decreases student } \\
\text { engagement and 'deep- } \\
\text { learning' }\end{array}$ & Lugosi and Jameson (2017) \\
\hline & $\begin{array}{l}\text { E-assessment and co-creation } \\
\text { of content are complex and } \\
\text { difficult to implement }\end{array}$ & $\begin{array}{l}\text { Xiao, Qiu and Cheng (2018); Barbera, } \\
\text { Garcia and Fuertes-Alpista (2017); Lin and } \\
\text { Cantoni (2018) }\end{array}$ \\
\hline
\end{tabular}

In general, some teachers seem to have mixed feelings as to the growing role of digital technology in educational contexts. On the one hand, the use of digital technology is perceived by some teachers as a "distraction and they felt less confident that students were paying attention to the teaching" (Lugosi and Jameson 2017, 166). They also consider that it contributes to a decrease in meaningful engagement with content, since students are not always capable of critically and accurately selecting and using information provided by search engines.

It is important to point out that the intensification of the teachers' workload may also prevent them from keeping pace with the development of digital solutions and consequently from innovating in their teaching practice. Cheung, Wan and Chan (2018, 10) point out that "training should be able to empower teachers to think about, or work with the technology in more different ways, rather than just teaching them how to use it". Besides, teachers should feel encouraged to use technology-based strategies on account of its ease-of-use and versatility in realising learning outcomes, and especially in meeting the needs of diverse student profiles (Patiar, Ma, Kensbock and Cox 2017; Schott 2017; Schaffer 2017). 
ToSEE - Tourism in Southern and Eastern Europe, Vol. 5, pp. 61-72, 2019

A. Balula, G. Moreira, A. Moreira, E. Kastenholz, C. Eusébio, Z. Breda: DIGITAL TRANSFORMATION ...

On the other hand, as Chiao, Chen and Huang (2017) stress, digitalization can promote more integrated and multidisciplinary approaches to teaching and curriculum design. This is only possible if the use of digital technology is grounded on well-defined learning outcomes, enables authentic learning experiences, supports access to multi-format information sources and integrates them in the teaching and learning process (Patiar, Ma, Kensbock and Cox, 2017). Furthermore, digitalization allows the tracking of students' performance and the provision of just-in-time feedback, i.e. formative assessment (Cheung, Wan and Chan, 2018; Patiar, Ma, Kensbock and Cox 2017). Barbera, Garcia, and Fuertes-Alpista (2017), however, also point out that the co-design and co-creation of content, as well as teaching/learning/assessment strategies, especially when negotiated between teachers and students, are not easy tasks.

Time and space flexibility are two of the most widely accepted advantages of using digital technology in educational contexts (Patiar, Ma, Kensbock and Cox 2017). Virtual reality, in particular, seems to play a very important role in Tourism Education settings, since it offers the "adaptability needed for groups of part-time, mature and international students, and meets the self-efficacy component of successful blended learning" (Patiar, Ma, Kensbock and Cox 2017, 136), and its ubiquitousness favours equitable learning opportunities (Chiao, Chen and Huang 2017; Schaffer 2017).

One of the most relevant facets of digital technology, and in particular of virtual reality, is the possibility it presents for the development of situated understanding of contents (Chiao, Chen and Huang 2017). Thus, teaching and learning strategies grounded in the use of virtual reality (Web 3.0), as well as game-based learning, for instance, support and enhance field work experience based on industry needs, fostering authentic learning experiences through narratives (Patiar, Ma, Kensbock and Cox 2017; Schaffer 2017; Schott 2017). In fact, virtual reality environments in Tourism are emergent, in particular because they allow for innovation through real-world simulation (Chiao, Chen and Huang 2017), subsequently promoting students' self-confidence and critical thinking (Schott 2017). The integration of authentic virtual settings in Tourism Education thus leverages students' engagement and interaction at a deeper level, boosting their intrinsic motivation (Chiao, Chen and Huang 2017; Schott 2017).

Concerning the development of competencies, Xiao, Qiu and Cheng $(2018,1)$ point out that the "inadequacies [of MOOCs] in training and assessing higher-order practical competencies" still remain a challenge and that an in-depth development of soft skills and practical competencies is still not fully addressed in online educational environments. Lin and Cantoni (2018) report that collaboration-based teaching and learning strategies also seem to be in general avoided in MOOCs and that discussion forums and email are the most recurrent tools used in MOOCs and in extra-MOOC interaction, respectively. Lugosi and Jameson $(2017,166)$ had already supported these results, arguing that "because hospitality was so people-centric, reliance on online delivery meant that key interpersonal and communication skills and technical competencies could not be developed effectively and would reduce students' employability". 
ToSEE - Tourism in Southern and Eastern Europe, Vol. 5, pp. 61-72, 2019

A. Balula, G. Moreira, A. Moreira, E. Kastenholz, C. Eusébio, Z. Breda: DIGITAL TRANSFORMATION ...

From the students' viewpoint, the use of social networking tools (such as Facebook and Twitter) could have a positive impact on their learning (Lin and Cantoni 2018). Notwithstanding, several authors (e.g. Patiar, Ma, Kensbock and Cox 2017; Schott 2017; Schaffer 2017) conclude that there is evidence of the learning effectiveness of technology use, as well as a good acceptance of digital technology within Tourism Education settings (Chiao, Chen and Huang 2017, 29), in particular of virtual reality solutions (e.g.: Second Life environments or tour-guiding platforms such as the Cultural Tourism Digital Guiding Platform or InstaVR platform). Thus, virtual reality helps bridge theory with practice, since "prior to joining the industry in the forms of internships, part-time or fulltime jobs, participation in collaborative and creative team work involving critical thinking, problem-solving, decision making and knowledge creation is very important" (Patiar, Ma, Kensbock and Cox 2017, 136). Moreover, game-based learning strategies grounded in virtual reality also minimise emotional barriers to communication and promote a higher level of engagement (Enticknap-Seppänen 2017).

Finally, the authenticity offered by technology-based learning settings also seems to favour reflection on tourism professional identity. Thus, the use of digital technology can boost students' professional awareness and understanding, as well as their confidence about career opportunities, since they tend to feel more competitive and responsive to interact in future professional environments (Enticknap-Seppänen 2017; Padron, Fortune, Spielman and Tjoei 2017).

\section{CONCLUSION}

With digital technology playing a pivotal role both in the industry and in students' lives, it is important for Tourism Education to embrace digital transformation, keeping up with the developments and changes in progress. This study makes a valuable contribution to the on-going discussion on the need to reshape Tourism Education, by addressing not only the students' but also the faculty members' needs. It reveals a dual focus: on the use of digital technology in the teaching and learning process on the one hand; and on the other, the development of digital competence in context - and both are regarded as crucial for current and future Tourism professionals. It also makes a valuable contribution to other fields of higher education, which are grappling with similar pressures and challenges regarding digitalisation.

Several tendencies emerge from this study. Firstly it seems apparent that while teaching faculty face time and training constraints in the use of digital technologies and its formats, students are taken to be digital natives, intent on using their digital competencies in support of their learning but also in the development of their future professional knowledge and skills. In Tourism Education, digital media offer a wealth of opportunity for the latter, for the enrichment of the traditional learning experience and for the development of the soft skills so relevant to the tourism and hospitality professional. On the other hand, faculty appear to fear the loss of control over students and their learning if they innovate too far in the digital direction. We suggest that this fear of losing control as teachers to digital media is a common one across disciplinary areas, impeding the necessary adjustment of teacher role, from lecturer to tutor, guide, learner (even). 
ToSEE - Tourism in Southern and Eastern Europe, Vol. 5, pp. 61-72, 2019

A. Balula, G. Moreira, A. Moreira, E. Kastenholz, C. Eusébio, Z. Breda: DIGITAL TRANSFORMATION ...

Associated with this is the tendency for technology and internet access to information to shape how students engage with learning and teaching, leading to a perceived decline in the critical consumption of information. At the same time, students' multitasking with technology is often seen to exasperate fragmented engagement and disrupt 'deep learning', particularly during classes. Clearly there is a need to invest in equipping teachers with a better understanding of how technology can positively impact learning and enhanced competencies in taking advantage of the opportunity it can offer to expand the ambit of the normal classroom and the confined curriculum, opening the way to virtual and real learning experiences so promising for learners and future professionals. The teaching modules being developed within the project "Future Proof Your Classroom - Teaching Skills 2030" (ref. 2017-1-AT01-KA203-034984) are an example of what can be done in this field.

In effect, our study reveals how technology can be used to enhance delivery and support flexible engagement for students, for example, in the use of lecture capture and podcasting. The multiple delivery modes supported by technology and the range of available learning platforms not only offer a more personalised range of options for learners, but an opportunity for a wider access to Tourism (and other) Education for diverse and non-traditional publics. Despite the reluctance on the part of often hardpressed teachers to adopt technology-based methods and learning settings, the studies analysed here reveal that blended learning solutions can offer the most advantage to learners and future professionals. However, their implementation requires the development of new competencies and processes and their development and utilisation is dependent on staff and the institutions' willingness and ability to invest in resources, which may not always be viable as competition for resources and pressures for outputs increase. It also emerged from our readings that the enforced top-down implementation of MOOCs, for example, as a cost-saving strategy, has not produced sustainable results, indicating that staff and students must be involved in a collaborative effort to innovate teaching and learning practices.

\section{ACKNOWLEDGEMENTS}

This work was financially supported by: i) the Research Unit on Governance, Competitiveness and Public Policy (project POCI-01-0145-FEDER-008540), funded by FEDER funds through COMPETE 2020 - Programa Operacional Competitividade e Internacionalização (POCI) - and by national funds through FCT - Fundação para a Ciência e a Tecnologia, ii) the Research Centre on Didactics and Technology in the Education of Trainers (project UID/CED/00194/2019), and iii) the UA Centre for Languages, Literatures and Cultures (project UID/ELT/04188/2016), both funded by national funds through FCT - Fundação para a Ciência e a Tecnologia, I.P. 
ToSEE - Tourism in Southern and Eastern Europe, Vol. 5, pp. 61-72, 2019

A. Balula, G. Moreira, A. Moreira, E. Kastenholz, C. Eusébio, Z. Breda: DIGITAL TRANSFORMATION ...

\section{REFERENCES}

Barbera, E., Garcia, I. and Fuertes-Alpiste, M. (2017), "A co-design process microanalysis: Stages and facilitators of an inquiry-based and technology-enhanced learning scenario", The International Review of Research in Open and Distributed Learning, Vol. 18, No. 6, doi: 10.19173/irrodl.v18i6.2805

Carretero, S., Vuorikari, R. and Punie, Y. (2017), DigComp 2.1: The Digital Competence Framework for Citizens with eight proficiency levels and examples of use, EUR $28558 \mathrm{EN}$. doi:10.2760/38842.

Cheung, G., Wan, K. and Chan, K. (2018), "Efficient use of clickers: A mixed-method inquiry with university teachers", Education Sciences, Vol. 8, No. 31, doi:10.3390/educsci8010031

Chiao, H.-M., Chen, Y.-L. and Huang, W.-H. (2018), "Examining the usability of an online virtual tour-guiding platform for cultural tourism education", Journal of Hospitality, Leisure, Sport \& Tourism Education, Vol. 23, pp. 29-38, doi: 10.1016/j.jhlste.2018.05.002

Dart, J. (2009), Learning and teaching guides: Problem based learning in sport, leisure and social sciences. URL: https://www.heacademy.ac.uk/system/files/ssg_pbl_casestudies.pdf

Dexeus, C. (2019), "The deepening effects of the digital revolution", in Fayos-Solá, E. and Cooper, C. (Eds), The future of tourism, Springer, Cham, pp. 43-69. doi:10.1007/978-3-319-89941-13

Enticknap-Seppänen, K. (2017), "Goofy Guide Game: Affordances and constraints for engagement and oral communication in English", In Borthwick, K., Bradley, L. and Thouësny, S. (Eds), CALL in a climate of change: Adapting to turbulent global conditions - short papers from EUROCALL 2017, Research-publishing.net, pp. 105-109, doi: 10.14705/rpnet.2017.eurocall2017.697

Fayos-Solá, E. and Cooper, C. (Eds.) (2018), The future of tourism: Innovation and sustainability, Springer.

Framke, W. (2002), "The Destination as a Concept: A Discussion of the Business-related Perspective versus the Socio-cultural Approach in Tourism Theory", Scandinavian Journal of Hospitality and Tourism, Vol. 2, No. 2, pp. 92-108, doi:10.1080/15022250.2014.886100

Law, R., Buhalis, D. and Cobanoglu, C. (2014), "Progress on information and communication technologies in hospitality and tourism", International Journal of Contemporary Hospitality Management, Vol. 26, No. 5, pp.727-750, doi:10.1108/IJCHM-08-2013-0367

Lin, J. and Cantoni, L. (2018), "Decision, implementation, and confirmation: Experiences of instructors behind tourism and hospitality MOOCs", International Review of Research in Open and Distributed Learning, Vol. 19, No. 1, pp. 275-293.

Lugosi, P. and Jameson, S. (2017), "Challenges in hospitality management education: Perspectives from the United Kingdom", Journal of Hospitality and Tourism Management, Vol. 31, pp. 163-172, doi:10.1016/j.jhtm.2016.12.001

Padron, T.C., Fortune, M.F., Spielman, M. and Tjoei, S. (2017), "The job shadow assignment: Career perceptions in hospitality, recreation and tourism", Research in Higher Education Journal, Vol. 32

Patiar, A., Ma, E., Kensbock, S. and Cox, R. (2017), "Students' perceptions of quality and satisfaction with virtual field trips of hotels", Journal of Hospitality and Tourism Management, Vol. 31, pp. 134141, doi:10.1016/j.jhtm.2016.11.003

Schaffer, V. (2017), "Enhancing learning to diverse cohorts via immersive visualization", Journal of Hospitality, Leisure, Sport \& Tourism Education, Vol. 21, pp. 46-54, doi: $10.1016 /$ j.jhlste.2017.07.001

Schott, C. (2017), "Virtual fieldtrips and climate change education for tourism students", Journal of Hospitality, Leisure, Sport \& Tourism Education, Vol. 21, pp. 13-22, doi: $10.1016 /$ j.jhlste.2017.05.002

Sharafuddin, M.A., Sawad, B.P. and Wongwai, S. (2017), "Modeling and mapping personal learning environment of Thai international higher education students", Asian Journal of Education and Training, Vol. 4, No. 1, pp. 35-40 doi: 10.20448/journal.522.2018.41.35.40.

Tavakoli, R. and Wijesinghe, S.N.R. (2019), "The evolution of the web and netnography in tourism: A systematic review", Tourism Management Perspectives, Vol. 29, pp. 48-55, doi: 10.1016/j.tmp.2018.10.008

World Economic Forum (2017), Digital Transformation Initiative: Aviation, Travel and Tourism Industry, Geneva:Switzerland. URL: http://reports.weforum.org/digital-transformation/wpcontent/blogs.dir/94/mp/files/pages/files/wef-dti-aviation-travel-and-tourism-white-paper.pdf

Xiao, C., Qiu, H. and Cheng, S.M. (2019), "Challenges and opportunities for effective assessments within a quality assurance framework for MOOCs", Journal of Hospitality, Leisure, Sport \& Tourism Education, Vol. 24, pp. 1-16, doi: 10.1016/j.jhlste.2018.10.005 
ToSEE - Tourism in Southern and Eastern Europe, Vol. 5, pp. 61-72, 2019

A. Balula, G. Moreira, A. Moreira, E. Kastenholz, C. Eusébio, Z. Breda: DIGITAL TRANSFORMATION ...

Ana Balula, $\mathrm{PhD}$, Assistant Professor

University of Aveiro, Águeda School of Technology and Management

Research Centre on Didactics and Technology in the Education of Trainers

Apartado 473, 3754 - 909 Águeda, Portugal

Phone: +351234611500

E-mail: balula@ua.pt

Gillian Moreira, $\mathrm{PhD}$, Assistant Professor

University of Aveiro, Department of Languages and Cultures

Research Centre for Languages, Literatures and Cultures

Campus Universitário de Santiago, 3810 - 193 Aveiro, Portugal.

Phone: +351234370358

E-mail: gillian@ua.pt

António Moreira, PhD, Associate Professor

University of Aveiro, Department of Education and Psychology

Research Centre on Didactics and Technology in the Education of Trainers

Campus Universitário de Santiago, 3810-193 Aveiro, Portugal

Phone: +351234 372567

E-mail: moreira@ua.pt

Elisabeth Kastenholz, $\mathrm{PhD}$, Associate Professor University of Aveiro, Department of Economics, Management, Industrial Engineering and Tourism Research Unit on Governance, Competitiveness and Public Policies Campus Universitário de Santiago, 3810-193 Aveiro, Portugal Phone: +351 234370361

E-mail: elisabethk@ua.pt

Celeste Eusébio $\mathrm{PhD}$, Assistant Professor

University of Aveiro, Department of Economics,

Management, Industrial Engineering and Tourism

Research Unit on Governance, Competitiveness and Public Policies

Campus Universitário de Santiago, 3810-193 Aveiro, Portugal

Phone: +351234370 361

E-mail: eleste.eusebio@ua.pt

Zélia Breda, PhD, Assistant Professor

University of Aveiro, Department of Economics, Management, Industrial Engineering and Tourism

Research Unit on Governance, Competitiveness and Public Policies Campus Universitário de Santiago, 3810-193 Aveiro, Portugal

Phone: +351 234370361

E-mail: zelia@ua.pt 